\title{
Pictorial Identification Key for Blowflies (Diptera, Calliphoridae) of Potential Forensic Importance in Korea
}

Bong-Hwan Ji, Sang-Hyun Park, Tae-Young Moon

Department of Biomedical Sciences, Kosin University, Busan, Korea

Received: August 26, 2020

Revised: November 9, 2020

Accepted: February 24, 2021

\section{Correspondence to}

Tae-Young Moon

Department of Biomedical Sciences, Kosin University, Wachi-ro 194,

Yeongdo-gu, Busan 49104, Korea

Tel: +82-51-990-2156

Fax: +82-51-911-2504

E-mail:tymoon@kosin.ac.kr
The aim of this study was to investigate necrophagous blowflies to confirm their forensic importance in criminal investigations and to produce a pictorial key to easily identify blowflies that are likely to be present at the scene of death. Of the 26 calliphorid species recorded in Korea, 16 species were sampled from 103 animal cadavers including 63 rabbits and 40 pigs. We identified 13 species in Calliphorinae, Aldrichina grahami (Aldrich), Calliphora nigribarbis Vollenhoven (= C. lata Coquillett), C. subalpina (Ringdahl), C. vicina (RobineauDesvoidy), C. vomitoria (L.), Hemipyrellia ligurriens (Wiedemann), Lucilia ampullacea Villeneuve, L. caesar (L.), L. cuprina (Wiedemann), L. illustris (Meigen), L. papuensis Macquart, L. porphyrina (Walker), and L. sericata (Meigen), and three species in Chrysomyinae, Chrysomya megacephala (F.), Ch. pinguis (Walker), and Ch. rufifacies (Macquart). They were repeatedly recorded from various localities in different habitats and seasons. These species should be given importance in approaches to forensic science particularly as their ecological implications are well understood. An identification key for these forensically essential species is prepared in a user-friendly manner using characteristics easily visible to the bare eye or at least under a magnifying glass.

Key Words: Forensic entomology; Calliphoridae; Pictorial key; Identification; Korea

\section{Introduction}

Forensic entomology is the study of the systematics and ecology of insects associated with human and animal cadavers. Several reliable experiences and knowledge of entomology have provided clues based on insect evidence in criminal investigations [1,2]. In particular, local insects approaching cadavers may have different compositions in different localities, and the usual range of these insects would be $10-100 \mathrm{~km}^{2}$ [3,4]. Therefore, faunal information for criminal investigation should be more comprehensive at the national and local levels.

Flies in Calliphoridae are one of the most important insects in forensic entomology. They can provide information on postmortem colonization of the remains and postmortem intervals [5]. The family Calliphoridae, commonly known as blowflies or cluster flies, has 1,500 species in five subfamilies recorded to date worldwide [6].

Many experts have contributed to blowfly taxonomy; 26 species belonging to 14 genera and four subfamilies have been recorded in Korea [7-11]: 20 species in Calliphorinae, five species in Chrysomyinae, one species in Polleniinae, and two species in Rhiniinae that have recently been revised as the family Rhiniidae. 
However, their local guilds and ecological interactions with animal cadavers have not been clearly studied. Nevertheless, blowflies are a requisite taxon for forensic or criminal investigations. In Korea, calliphorid species have not been assessed in terms of forensic entomology. We carefully investigated the species for potential forensic importance and sampled 16 calliphorid species from animal cadavers that we set up as traps. We suggest an inventory of calliphorid species of potential forensic importance and present a pictorial key for user-friendly identification by those not familiar with entomology.

\section{Materials and Methods}

We used 103 animal cadavers of rabbits $(n=63)$ and pigs $(n=40)$ to sample the calliphorid species and observed their activities through the decomposition process between May 2016 and November 2019. The investigated sites were chosen from seven different localities considering the geographical arrangement in South Korea: Namyangju in Gyeonggi-do, Okcheon in Chungcheongbuk-do, Mokpo and Haenam in Jeollanamdo, Changwon and Miryang in Gyeongsangnam-do, and Yeoungdo in Busan.

The pictorial key is prepared in a user-friendly context to support taxonomic novices with a magnifying glass. We attempted to choose, if possible, a limited number of external characteristics, such as body color, hair or setae, thorax stripes, and dark abdomen bands, referring to Kano and Shinonaga [12] and Akbarzadeh et al. [13]. The essential taxonomic characteristics and terms used in the pictorial key are described in schematic diagrams of the adult body (Fig. 1), ventral view of the head (Fig. 2),
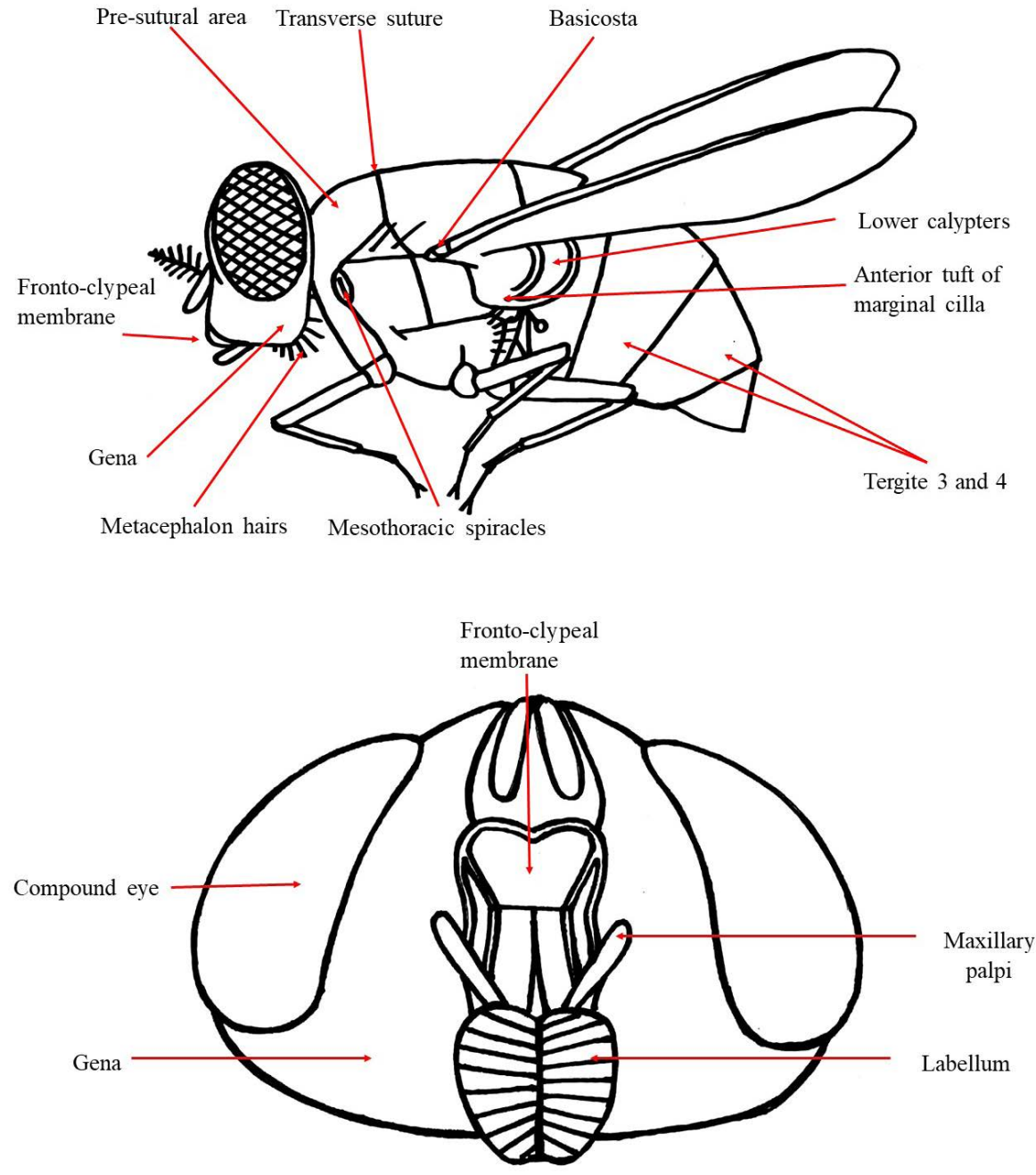

Fig. 1. Lateral view of a calliphorid fly.

Fig. 2. Frontal view of the head of a calliphorid fly. 
and wing structure (Fig. 3).

\section{Results}

All 26 calliphorid species recorded in Korea are listed in Table 1, including the 16 species recorded exclusively from animal cadavers in our experiment. Thirteen species belonged to Calliphorinae, Aldrichina grahami (Aldrich), Calliphora nigribarbis Vollenhoven (= C. lata Coquillett) [14], C. subalpina (Ringdahl), C. vicina (Robineau-Desvoidy), C. vomitoria (L.), Hemipyrellia ligurriens (Wiedemann), Lucilia ampullacea Villeneuve, L. caesar (L.), L. cuprina (Wiedemann), L. illustris (Meigen), L. papuensis Macquart, L. porphyrina (Walker), and L. sericata (Meigen), and three species were from Chrysomyinae, Chrysomya megacephala (F.), Ch. pinguis (Walker), and Ch. rufifacies (Macquart). In particular, Ch. rufifacies is newly recorded in Korea, as reported elsewhere [13]. These fly species gathered and fed on the rabbit and pig cadavers provided during the investigation. Therefore, we produced a pictorial key based on these 16 calliphorid species as being of potential forensic importance (Fig. 4).

\section{Discussion}

Flies are the most common visitors to decomposing organic matter. Extensive knowledge is available on

Table 1. Calliphorid species recorded in Korea

\begin{tabular}{|c|c|c|c|c|c|c|c|}
\hline Family & Scientific name & $A$ & B & C & $\mathrm{D}$ & $\mathrm{E}$ & Note \\
\hline \multirow[t]{11}{*}{ Calliphorinae } & Aldrichina grahami & + & + & + & + & + & \\
\hline & Bellardia nartsukae & - & + & + & + & - & Onesia to Bellardia \\
\hline & Calliphora nigribarbis & + & + & + & + & + & Syn. Calliphora lata \\
\hline & Calliphora subalpina & - & + & + & + & + & \\
\hline & Calliphora vicina & - & + & + & + & + & \\
\hline & Calliphora vomitoria & + & + & + & + & + & \\
\hline & Melinda pusilla pusilla & - & + & + & + & - & \\
\hline & Onesia koreana & - & + & + & + & - & \\
\hline & Polleniopsis chosenensis & - & + & + & + & - & \\
\hline & Polleniopsis menechma & - & - & - & + & - & \\
\hline & Triceratopyga calliphoroides & + & + & + & + & - & \\
\hline \multirow[t]{14}{*}{ Chrysomyinae } & Chrysomya megacephala & - & + & + & + & + & \\
\hline & Chrysomya pinguis & + & + & + & + & + & \\
\hline & Chrysomya rufifacies & - & - & - & - & + & \\
\hline & Phormia regina & - & + & + & + & + & \\
\hline & Protocalliphora azurea & - & + & + & + & - & \\
\hline & Hemipyrellia ligurriens & + & + & + & + & + & \\
\hline & Lucilia ampullacea & + & + & + & + & - & \\
\hline & Lucilia bazini & + & + & + & + & - & \\
\hline & Lucilia caesar & + & + & + & + & + & \\
\hline & Lucilia cuprina & + & + & + & + & + & Phenicia to Lucilia \\
\hline & Lucilia illustris & + & + & + & + & + & \\
\hline & Lucilia papuensis & - & + & + & + & + & \\
\hline & Lucilia porphyrina & + & + & + & + & + & \\
\hline & Lucilia sericata & + & + & + & + & + & Phenicia to Lucilia \\
\hline Polleniinae & Pollenia japonica & - & + & + & + & - & \\
\hline
\end{tabular}

A, Park (1971) [7]; B, The Entomological Society of Korea and Korean Society of Applied Entomology (1994) [8]; C, Paek et al. (2010) [9]; D, National Biodiversity Center (2019) [10]; E, Current investigation between 2016 and 2019. 


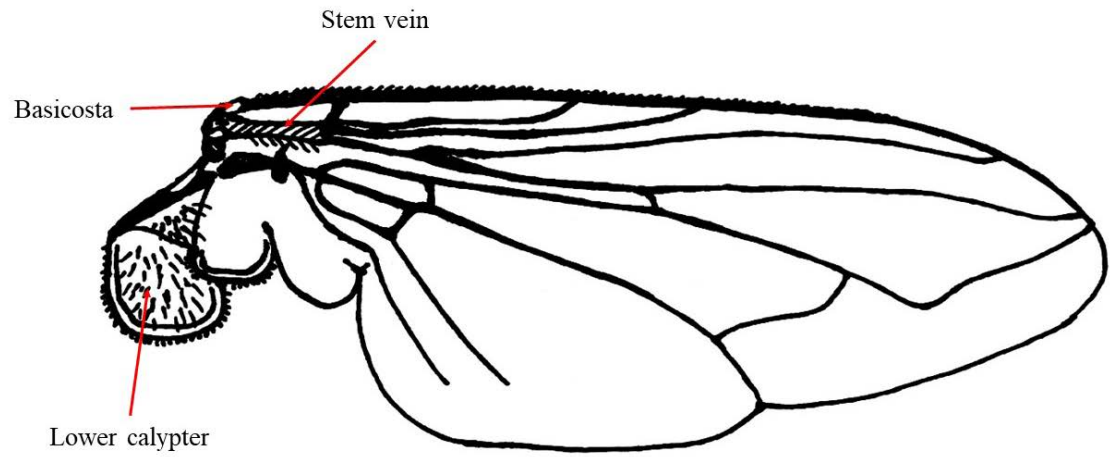

Fig. 3. Vein view of the calliphorid wing.

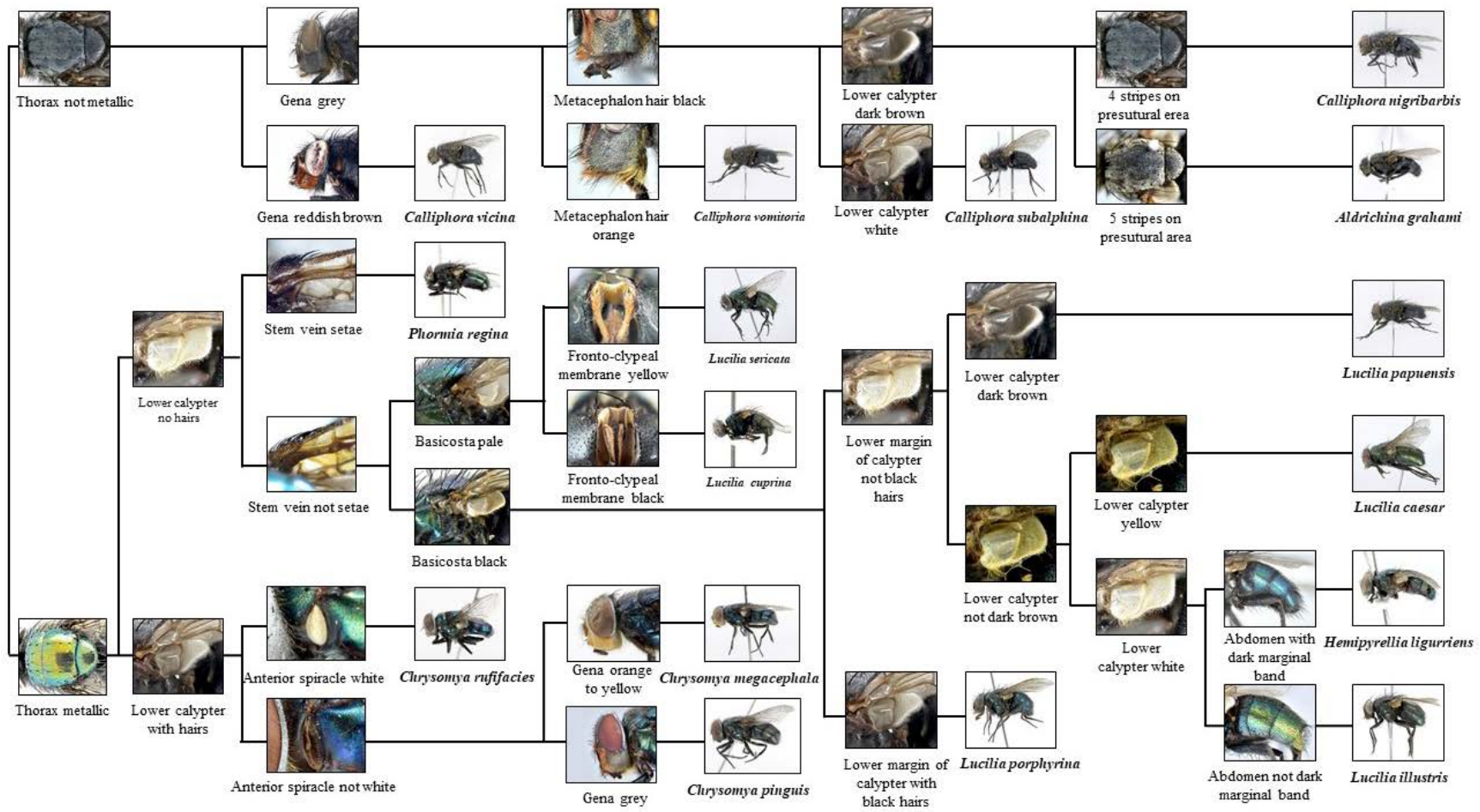

Fig. 4. Supported pictorial key of calliphorid flies of forensic importance in Korea.

flies; therefore, more meaningful implications may be added to forensic entomology. For forensic entomology, knowledge of the local fauna of flies is a fundamental requirement and better results can be obtained if there is adequate and suitable database information. We utilized our calliphorid inventory to check and confirm which species are likely significant and useful for forensic and criminal investigations. Although human cases were not included, the calliphorid species suggested may be tentatively considered to be of forensic importance owing to their repeated and continuous approaches to animal cadavers [15-17].
Although Ch. rufifacies has been recorded in Australia [18] it has been found in many scattered locations around the world. The species has been suggested to exist in Korea based on DNA research (Dr. Shin SE, 2020, personal communication). The specimen in this study was morphologically cross-examined by entomologists in Korea and Japan (Dr. Sueyoshi M, 1999, examined in Kumamoto). The taxonomic report of this species from Korea is published elsewhere [13]. However, this species is rare in appearance and distribution in Korea.

Although the entomological knowledge required in forensic and crime scenes may be different based on the 
particular situation, it is necessary to equip investigators with quick and easy identification methods. Therefore, we retrieved, collated, and tested various taxonomic characteristics and consequently selected the most relevant characteristics to produce a user-friendly identification key. This key is designed to distinguish those calliphorid flies aggregating on animal cadavers, possibly extending to human cadavers as well, with a quality magnifying glass.

ORCID: Bong-Hwan Ji: https://orcid.org/0000-0003-20073605; Sang-Hyun Park: https://orcid.org/0000-0003-10969272; Tae-Young Moon: https://orcid.org/0000-00032123-9099

\section{Conflicts of Interest}

No potential conflict of interest relevant to this article was reported.

\section{Acknowledgments}

This research was supported by Projects for Research and Development of Police Science and Technology under the Center for Research and Development of Police Science and Technology and the Korean National Police Agency (PA-G000001).

\section{References}

1. Hall RD. Medicocriminal entomology. In: Catts EP, Haskell NH, eds. Entomology and death: a procedural guide. Clemson: Joyce's Print Shop Press; 1990. p. 1-8.

2. Introna F, Campobasso CP, Di Fazio A. Three case studies in forensic entomology from southern Italy. J Forensic Sci 1998;43:210-4.

3. Whittlesey $D$. The regional concept and the regional method. In: James PE, Jones CF, eds. American geography: inventory and prospect. Syracuse, NY: Syracuse University Press; 1954. p. 19-68.
4. Delcourt HR, Delcourt PA. Quaternary landscape ecology: relevant scales in space and time. Landsc Ecol 1988;2:23-44.

5. Catts EP, Goff ML. Forensic entomology in criminal investigations. Annu Rev Entomol 1992;37:253-72.

6. Pape T, Blagoderov V, Mostovski MB. Order Diptera Linnaeus, 1758. In: Zhang ZQ, ed. Animal biodiversity: an outline of higherlevel classification and survey of taxonomic richness. Zootaxa 2011;3148:222-9.

7. Park SH. The Muscidae, Calliphoridae and Sarcophagidae. In: Kim CW, Park SH, Lee GY, et al., eds. Illustrated encyclopedia of Diptera of Korea. Seoul: Sam Hwa Publishing; 1971. p. 949-1042.

8. The Entomological Society of Korea, Korean Society of Applied Entomology. Check list of insects from Korea. Seoul: Konkuk University Press; 1994. p. 305.

9. Paek MK, Hwang JM, Jung KS, et al. Checklist of Korean insects. Seoul: Nature \& Ecology; 2010. p. 243-4.

10. National Biodiversity Center 2019 [Internet]. Incheon: National Biodiversity Center; 2019 [cited 2019 Nov 25]. Available from: http://www.kbr.go.kr/stat/ktsnfiledown/downpopup.do.

11. Park SH, Zhang Y, Yu DH, et al. DNA-based identification of forensically important blow fly species in Korea: Aldrichina grahami, Calliphora lata, Calliphora vicina and Phormia regina. Korean J Leg Med 2006;30:140-6.

12. Kano R, Shinonaga S. Fauna Japonica, Calliphoridae (Insecta: Diptera). Tokyo: Biogeographical Society of Japan; 1968. p. 73114.

13. Akbarzadeh K, Wallman JF, Sulakova H, et al. Species identification of Middle Eastern blowflies (Diptera: Calliphoridae) of forensic importance. Parasitol Res 2015;114:1463-72.

14. Verves YG. An annotated check-list of Calliphoridae (Diptera) of the Russian Far East. Far East Entomol 2002;116:1-14.

15. Carvalho LM, Thyssen PJ, Linhares AX, et al. A checklist of arthropods associated with pig carrion and human corpses in southeastern Brazil. Mem Inst Oswaldo Cruz 2000;95:135-8.

16. Grassberger M, Friedrich E, Reiter C. The blowfly Chrysomya albiceps (Wiedemann) (Diptera: Calliphoridae) as a new forensic indicator in Central Europe. Int J Legal Med 2003;117:75-81.

17. Gruner SV, Slone DH, Capinera JL. Forensically important calliphoridae (Diptera) associated with pig carrion in rural northcentral Florida.J Med Entomol 2007;44:509-15.

18. Illnigworth JF. The Australian sheep fly in Hawaii. Proc Hawaii Entomol Soc 1918;3:429. 